\title{
ECONOMIC CONVERGENCE AND ECONOMIC POLICIES
}

Jeffrey D. Sachs

Andrew M. Warner

Working Paper No. 5039

\section{NATIONAL BUREAU OF ECONOMIC RESEARCH 1050 Massachusetts Avenue Cambridge, MA 02138 \\ February 1995}

We thank Robert Barro, Bradford DeLong, Robert King, Jong-Wha Lee, Ross Levine, Lant Pritchett and Lawrence Summers for sharing their data with us, and seminar participants at UCLA and Berkeley for helpful comments. This paper is part of NBER's research programs in International Finance and Macroeconomics and Growth. Any opinions expressed are those of the authors and not those of the National Bureau of Economic Research.

(C) 1995 by Jeffrey D. Sachs and Andrew M. Warner. All rights reserved. Short sections of text, not to exceed two paragraphs, may be quoted without explicit permission provided that full credit, including (C) notice, is given to the source. 


\title{
ECONOMIC CONVERGENCE AND \\ ECONOMIC POLICIES
}

\begin{abstract}
Many of the crucial debates in development economics are encapsulated in the question of economic convergence. Is there a tendency for the poorer countries to grow more rapidly than the richer countries, and thereby to converge in living standards? Some recent research on endogenous growth has emphasized increasing returns as a possible reason not to expect convergence. Other research has suggested that convergence may be achieved only after poor countries attain a threshold level of income or human capital. This paper presents evidence that a sufficient condition for higher-than-average growth of poorer countries, and therefore convergence, is that poorer countries follow reasonably efficient economic policies, mainly open trade and protection of private property rights.
\end{abstract}

Jeffrey D. Sachs

Department of Economics

Harvard University

Cambridge, MA 02138

and NBER
Andrew M. Warner

Harvard Institute for

International Development

Harvard University

Cambridge, MA 02138 


\section{Introduction}

Many of the crucial debates in development economics are encapsulated in the question of economic convergence. Is there a tendency for the poorer countries to grow more rapidly than the richer countries, and thereby to converge in living standards? Or instead, are there tendencies for the "rich to get richer, and the poor to get poorer," so that the gap between rich and poor nations tends to widen over time?

An enormous professional debate over this issue has been underway during the past decade, instigated by several theoretical and empirical insights. Paul Romer (1986) provided a major spur to the debate by introducing a theoretical growth model with increasing-returns-to-scale production technology, which results in a strong tendency for rich countries to maintain or even increase their lead over poorer countries. Romer stressed that the more standard technology assumptions of the Solow growth model lead to the presumption that the poorer countries would experience faster growth ${ }^{1}$. Romer noted that his theoretical model with increasing returns to scale seemed to be broadly consistent with the cross-country growth experience of the post-war era, in which there was no discernable trend for the poorer nations to converge with the richer nations. ${ }^{2}$

1 More precisely, as Mankiw, Romer and Weil (1992) have clarified, the Solow model predicts conditional convergence: countries will have different steady state income levels, but after controlling for the determinants of the steady state income level, the poorer countries should grow faster than richer countries.

2 He was also careful, however, to point out the problem of interpreting such simple correlations:

Cross-country comparisons of growth rates are complicated by the difficulty of controlling for political and social variables that 
Romer's point about the absence of convergence is evident in Figure 1. We graph on the $x$-axis the 1970 level of per capita income of several dozen developing countries, and on the y-axis the growth of per capita income between 1970-89.3 If convergence predominated in the data, then we would find a negative relationship between initial income in 1970 and subsequent growth between 1970 and 1989. No such tendency is found overall in the world economy during this time period. Many poor countries, particularly those in Sub-Saharan Africa, not only fail to grow faster than the rich countries; they in fact experience negative per capita growth, so that the gap between these countries and the rich countries widens significantly.

Romer's theoretical model and empirical insight set off a decade-long debate which still continues. Many authors, such as Dowrick and Nguyen (1989), demonstrated that convergence seemed to hold among the richest countries alone, specifically those countries in the Organization for Economic Cooperation and Development (OECD) ${ }^{4}$. Baumol and others suggested that there may be a "convergence club," meaning a subset of countries for which convergence applies, while countries outside of "club" would not necessarily experience convergence via-a-vis those in the club:

It also seems clear that convergence does not apply to the poorest of the world's economies, though the line separating those eligible for membership in the convergence club and those foreclosed from membership

appear to strongly influence the growth process.

3 The exact definitions of the data and the selection of countries is described in the Appendix.

4 Interestingly, Williamson (1993) presents further evidence that among the current members of the OECD, convergence has been going on since 1850, interrupted only by the four decades between 1913 and 1950 . 
has not been determined definitively. (Baumo1, 1994, p. 82)

Baumol suggested that only countries with an adequate initial level of human capital endowments can take advantage of modern technology to enjoy the possibility of convergent growth. Baumol (1994, p. 65) therefore speaks of the "advantages of moderate backwardness," arguing that while middle-income developing countries can take advantage of their lag in technology to borrow from abroad, the poorest countries are unable to bridge the gap in technology and knowledge.

Barro (1991) and Barro and Sala-1-Martin (1991, 1992) introduced a related notion of "conditional convergence," in which countries purportedly differ in their long-run per capita income levels, with each country tending to grow more rapidly the greater is the gap between its initial per capita income level and its own long-run per capita income level. Formally, country $i$ is assumed to have the long-run per capita income level $y_{1} *$, and initial per capita income level $y_{i}$. The rate of growth, $\dot{y}_{i}$, is assumed to be an increasing function of the gap between $y_{1} *$ and $y_{1}$ :

$$
\dot{y}_{i}=\beta\left(y_{1} *-y_{1}\right)
$$

A positive value of $\beta$ is said to signify conditional convergence. In turn, $y_{1}$ * is proxied by certain "structural" variables, such as the initial level of human capital, according to an equation $y_{1} *-\Sigma \gamma_{j_{1}} z_{j_{1}}$. Barro and coauthors then estimate a regression equation of the form:

$$
\dot{y}_{i}-\beta\left(\Sigma \gamma_{j i} z_{j i}-y_{i}\right)
$$


They tend to find a positive and significant coefficient for $\beta$ and significant coefficients on several structural variables $Z^{5}$. Like Baumol, Barro 1991, p. 409) concludes that:

A poor country tends to grow faster than a rich country, but only for a given quantity of human capital; that is, only if the poor country's human capital exceeds the amount that typically accompanies the low level of per capita income.

In summary, there have been three dominant explanations offered in the 1iterature for the absence of convergence in Figure 1. The first holds that productive technology is intrinsically kind to the technological leader: the rich tend to grow richer as a result of increasing returns to scale in one form or another. ${ }^{6}$ The second holds that convergence is a fact of life, but only among countries with a sound human capital base for using modern technology. The third holds that currently poor countries simply have low long-term potential $\left(y_{i}^{*}\right)$, though countries do tend to grow faster the greater the gap between their current income and their own long-run potential. Any of these explanations, if correct, would lead to profoundly pessimistic conclusions for the poorest countries. Each concept suggests that the poorest countries will be unable to achieve rapid growth needed to close the gap with the richer countries.

5 The finding of conditional convergence is now fairly well established in the empirical literature. A number of studies have found this result using post-WWII data with different conditioning variables. The list of such studies includes Barro (1991), DeLong and Summers (1991), King and Levine (1993), Levine and Renelt (1992), Mankiw, Romer and Weil (1992), and Sachs and Warner (1994).

6 Increasing returns to scale is shorthand for a wide variety of technological possibilities, such as learning by doing, spillovers in knowledge accumulation, agglomeration economies among suppliers of specialized inputs to production, etc. 
We believe that all of these explanations of Figure 1 are too pessimistic regarding the potential for growth and convergence of the poorest countries. Economic growth, and therefore economic convergence, requires reasonably efficient economic institutions. Poorly managed economies - such as those with the absence of secure property rights, autarkic trade policies, inconvertible currencies, and so forth - are unlikely to experience convergence no matter what the underlying production technology or initial level of human capital. Since many, if not all, of the non-convergent countries failed to maintain adequate economic institutions during the postwar era, it is possible that it is reversible policy failures, rather than technology or human capital that explains their failure to grow. Put another way, the "convergence club" is better defined according to policy cholces rather than initial levels of human capital. We would also suggest that poor policy choices are reversible, not irrevocably linked to low levels of income ${ }^{7}$.

Such an interpretation is more in line with the cross-country evidence than interpretations suggesting an intrinsic failure of convergence. When we

7 It is interesting to note that in a paper that provoked much of the recent research on growth and convergence, Lucas (1988, p. 5, based on the Marshall lectures in 1985) wrote:

Is there some action a government of India could take that would lead the Indian economy to grow like Indonesia's or Egypt's? If so, what, exactly? ... The consequences for human welfare involved in questions like these are simply staggering: Once one starts to think about them, it is hard to think about anything else. (emphasis in the original)

We agree with Lucas that the policy question is central and see this paper as suggesting a basic answer to Lucas's question. Somewhat interestingly in light of this quote, P. Krishna and D. Mitra (1994), present evidence that India's trade liberalization of 1991 has led to increased productivity growth and lower price-marginal cost markups in a variety of industries. 
examine poor countries that have followed standard market-based economic policies, including respect for private property rights and open international trade, we note an overwhelming tendency towards convergence, even among countries that start with extremely low levels of human capital endowments and extremely low levels of initial per capita income. In fact, it is hard to find a single case in which a poor country actually protected private property rights and maintained economic openness, and yet failed to achieved economic growth. In essence, we subscribe to a much earlier, and widely cited judgment of Adam Smith ${ }^{8}$ :

Little else is requisite to carry a state to the highest degrees of opulence from the lowest barbarism, but peace, easy taxes, and tolerable administration of justice.

In our view, as in the view of Adam Smith, burdensome taxes on foreign trade (and related trade distortions such as import and export quotas) are of particular harm, since these not only distort economic incentives (e.g. pushing countries towards inefficient import-substituting industries), but they also cut countries off from international flows of knowledge.

In the next section of the paper, we demonstrate that good behavior in economic policy has been its own reward: all developing countries that have satisfied certain unexceptionable conditions on economic policy have experienced positive economic growth during the decades of the 1970s and 1980s, and in almost all cases these countries have shown a tendency to grow more rapidly than the developed economies, and thereby to converge. After

8 This aphorism is quoted by $A$. Leddin and B. Walsh, in The Macroeconomy of Ireland, Gill \& McMillan, 1995. These authors in turn refer to the citation in Paul Kennedy, The Rise and Fall of Great Powers. 
demonstrating this point, we then undertake a cross-country regression analysis based on equation (2), to try to determine some of the specific ways that poor economic policies have affected the growth dynamics of developing countries.

II. Economic Policies and Economic Convergence

In this section we define a subset of countries that have sustained "appropriate" market-based economic policies during the period of observation, 1970-89. We then examine whether there is a tendency towards economic convergence among this subset of qualifying countries during this sub-period. In essence, we examine whether there is a convergence club for all countries that have sustained adequate basic economic policies.

Our selection criteria are as follows. We start with the universe of all 135 countries in the Heston-Summers data series, and then eliminate 18 countries (combined population of more than 55 million) that lack some or all of the necessary underlying data. ${ }^{\circ}$ We then establish two basic subsets of "appropriate" policies: one set related to property rights and one set related to integration of the economy in international trade. All countries that pass both sets of criteria are considered to be countries that have pursued appropriate policies during the observation period. We call these the "qualifying" countries. Countries that fail at least one test are "nonqualifying." We then examine the growth dynamics of the qualifying and non-

9 Countries dropped from the sample because of insufficient data are: Afghanistan, Bahamas, Bahrain, Comoros, Dominica, Fiji, Grenada, Iceland, Kuwait, Oman, St. Lucia, St. Vincent, Saudi Arabia, Seychelles, Solomon Islands, Sudan, Surinam, United Arab Emirates. 
qualifying economies.

We note that many authors have previously used political and openness variables in cross-country growth studies and have often found these variables to be significant determinants of growth. These studies include Alesina, Ozler, Roubini, and Swagel (1992), Barro (1991), Bhalla (1994), DeLong and Summers (1991), Dollar (1992), Levine and Renelt (1992), and Svensson $(1994)^{10}$. Indeed, we rely on some of the data series that were generated by Barro (1991), Lee (1993), Levine and Renelt (1992), McMillan et. al. (1994) and Summers and Heston (1991). ${ }^{11}$ To our knowledge, however, no earlier studies have used such variables as filters to divide countries between "qualifying" and "non-qualifying" countries, in order to test whether economic convergence applies among the subset of countries following appropriate economic policies.

10 More specifically, Alesina et al. (1992) use measures of political instability and democracy indicators. Barro (1991) uses the number of revolutions, coups and assassinations and a dummy for Socialist countries. DeLong and Summers (1991) use several measures of outward orientation and price distortions. Levine and Renelt (1992) use the black market premium, number of revolutions and coups, a Socialist dummy, a civil liberties index, and measures of openness based on Leamer (1988). And Svensson (examining investment rather than growth) uses various measures for respect for property rights, contract enforcement, efficiency of legal institutions, and business risk, as well as measures of political repression. All of these studies examine the marginal contribution of the variables on the right side of a regression equation; none use these variables to sort countries into groups and examine the groups separately.

11 Interestingly, an association between convergence and openness across history has been noted by Williamson (1993). He argues that convergence and global economic integration have been associated since 1850. In the two sub-periods that saw relatively free movements of goods and factors, 1870-1913 and post-1950, there is evidence of convergence. In the period of restricted global trade between the two world wars, one does not find evidence for convergence. Ben-David (1993) also argues that income convergence within the members of the European Community was associated with the timing of trade liberalization. 
With regard to the property rights test, a country is non-qualifying (i.e. judged to have inappropriate policies) if it is characterized by at least one of the following three conditions:

(1) a socialist economic structure, according to the list of countries In Korna1 (1993);

(2) extreme domestic unrest, caused by revolutions, coups, chronic civil unrest, or a prolonged war with a foreign country that is fought on domestic territory;

(3) extreme deprivation of civil or political rights, according to the Freedom House index, reported in McMillan, et. al. (1994);

These criteria are selected because fallure on any of them would tend to undermine efficient long-term private capital accumulation (including human capital accumulation), which is a fundamental feature of economic growth. (Details on the variables and data sources are described in the Appendix). The second test is economic openness. One of the basic tenets of classical and neoclassical economics dating back to Adam Smith is the economic benefits of openness, including: increased specialization, efficient resource allocation according to comparative advantage, diffusion of international knowledge through trade, and heightened domestic competition as a result of international competition ${ }^{12}$.

12 Lucas (1988) and Young (1991) observe that much existing theory predicts a level effect rather than a growth effect from greater openness. The literature however is changing rapidly on this issue. Young (1991), Grossman and Helpman (1991), Eicher (1993) and Lee (1993) have proposed theoretical mechanisms by which increased trade can affect the long run growth rate. 
To test for openness, we include four kinds of measures. First, the country must not impose excessive quotas on imports. Second, the country must not impose excessive quotas, or state monopolies, on exports. Third, the country must maintain a reasonably convertible currency. We Judge convertibility according to the gap between the black market and official exchange rate. A large black market premium signals inconvertibility of the national currency, and thereby effective closure from world markets. ${ }^{13}$ Fourth, the country must not be socialist (as classified by Kornai, 1993). ${ }^{14}$ In addition, we exclude South Africa and the two countries located within South Africa (Lesotho and Swaziland) on the grounds of the international boycott of the South African economy during much of the period of observation.

Specifically, a country fails the openness test as a result of any of the following criteria (with details in the Appendix):

(1) a very high proportion of imports covered by quota restrictions, according to the index prepared by Lee (1993);

(2) for Sub-Saharan Africa, a high proportion of exports covered by state export monopolies and state-set prices, according to an index in the

13 As is well known, rationing of foreign exchange to importers at the official exchange rate is economically similar, if not identical, to a quota on imports.

14 Of course, the socialist countries fail on the other criteria. We use the Kornai list as an additional filter only because the other variables are not available for some of the socialist economies. In particular, by using the socialist criterion, we are able to classify Hungary, Poland, and Yugoslavia as closed economies, whereas the data sources we relied on do not have complete data for these countries. 
World Bank (1993) ${ }^{15}$;

(3) a socialist economic structure, according to the list of countries in Kornai (1993);

(4) a black-market premium over the official exchange rate of 20 percent or more, on average, either for the decade of the 1970 s or the decade of the 1980 s (or both).

Failure on any of these criteria indicates that the economy is operating in substantial isolation from the world economy ${ }^{16}$.

The list of non-qualifying countries according to any of the political or openness criteria is shown in Table 1, and the list of qualifying countries is shown in Table 2. It turns out that openness is the main determinant of whether a country is a non-qualifier. Virtually all countries that fail the political test also fail the openness test, with the two exceptions of Haiti

15 The World Bank index of monopolization of exports was constructed only for 29 Sub-Saharan African countries in the World Bank (1993) study on African structural adjustment. We are confident that none of the countries outside of Sub-Saharan Africa that we characterize as "qualifying" vis-avis openness should be disqualified on the basis of monopolization of exports. More generally, outside of Sub-Saharan Africa, trade quotas are overwhelmingly on the import side rather than the export side.

16 Pritchett (1993) shows that the correlations between several measures of "outward orientation" are quite low. This result has encouraged the view that measurement error is a severe problem with such measures (a conclusion not necessarily shared by Pritchett). We have three responses. First, we think that some of his variables actually measure different things, so that a low correlation is not necessarily surprising. We would put the trade share variable and the average import tariff variable in this category. Second, at least two of his variables, average tariffs and coverage of non-tariff barriers, are policy substitutes. The low correlation ( 0.36 ) may simply mean that some countries have chosen to close themselves with quotas and others with tariffs. Third, we try to minimize measurement error by using the trade indicators to sort countries into broad groups, rather than using all of the cardinal information in the data. 
(which had open trade but which denied civil and political rights) and Thailand (which had open trade but high political instability). ${ }^{17}$ Thus, if we exclude countries that are closed, we almost also exclude all countries that are non-qualifiers on political grounds. We find later on in the crosssection growth equations that the political variables do, however, help to explain the rate of economic growth in addition to the openness variables.

A statistical summary of the growth performance of the qualifying and non-qualifying countries is shown in Table 3 . We see that the non-qualifying low income countries have lower average growth rates than the qualifiers. We expect, therefore, that the qualifying developing countries are more likely to exhibit economic convergence once the non-qualifiers are dropped from the sample. It is notable that 23 of 29 countries with 1970 income levels above $\$ 4,000$ passed both the political and openness tests (income is measured in U.S. dollars, in purchasing-power-adjusted, constant 1985 prices), in contrast with just 12 out of 88 countries with initial income levels of less than $\$ 4,000$. However, the 12 low-income qualifiers have a higher average growth rate than the high-income qualifiers, which is consistent with the view that convergence tends to occur within the subset of countries that pursue appropriate economic policies.

The role of policy choices in convergence is dramatically evident in Figures 2(a) and 2(b), where we divide the sample in Figure 1 into groups of qualifying and non-qualifying countries. We should note that with very few

17 There are, in addition, three countries that fail the political test for which the openness variable is not avallable because of incomplete data. These countries are: Cape Verde, Liberia, and Panama. 
exceptions, We see in Figure $2(a)$ that the qualifying countries display a strong tendency towards economic convergence, with the countries with the initially low per capita income levels growing more rapidly than the richer countries. The non-qualifiers in Figure $2(b)$ do not display any tendency towards convergence. The non-qualifying countries in Figure 2(b) are clearly the source of the failure of convergence that we noted in Figure 1.

Even more strikingly, there is not a single country in our sample (which covers 117 countries and approximately 90 percent of the world's population as of 1985) which pursued appropriate policies during 1970-89 and yet which had per capita growth of less than 1.2 percent per year, and not a single qualifying developing country $(<\$ 4,000$ per capita) which grew at less than 2 percent per year! In fact, with the single exception of Haiti, there is not a single developing country that had substantially open trade and yet failed to grow by at least 2 percent per year. In this sense, the openness variable is almost a perfect determinant of the real "convergence club" in the world economy, a "club" based on policies available to all countries rather than on a country's initial level of income or educational attainment. By our count, there are 12 developing countries $(<\$ 4,000$ initial income) that pursued appropriate policies according to our criteria, and all grew at more than 2 percent per year.

So far we have analyzed growth per-capita rather than growth per-worker. The reason is that the per-capita growth rates are avallable for a longer time span than the per-worker growth rates, which often rely on less frequent census data. However, since some theories, (the Solow model in particular), predict convergence more precisely in terms of growth per-worker, it is worth examining the available data on growth per-worker. In figure 3 we present the 
result when figure $2(a)$ is redrawn with growth per-worker on the y-axis (covering the period 1970-85 rather than 1970-89). The figure shows stronger evidence for convergence than before; but we also find that growth is lower than before for the higher income economies. Based on this evidence, if growth per-worker were avallable for the full time period, we expect that it would strengthen our conclusions regarding convergence, but the minimum growth rate of the qualifying group would be about 0 percent rather than 2 percent. We plan to examine this further when data from the 1990 census rounds become available. ${ }^{18}$

In summary, we find no cases to support the frequent worry that a country might "do the right things" in terms of overall policy (both politics and openness), and yet fail to grow. Of course, economic reforms take time to work, so that some countries that have recently adopted outward-oriented market reforms (in the late 1980s or early 1990s) might not yet enjoy high growth rates as a result of those reforms. ${ }^{18}$

So far we have argued the case of sufficiency: a set of good policies is sufficient to produce a good economic outcome (i.e. convergent growth). What of necessity? Are there many countries that "broke the rules" and yet achieved high economic growth? There are seven countries that falled to qualify on one or more of the criteria and yet that had per capita growth of more than 3 percent per year during 1970-89: Botswana, Cape Verde, China,

18 This result that per-worker growth exhibits stronger evidence for convergence than per-capita growth is also observed by Wolf (1994).

19 On the other hand, there are many recent reformers that are already experiencing rapid economic growth, such as Argentina, Bolivia, and Peru in Latin America, and Poland, Estonia, Slovenia in post-communist Central and Eastern Europe. We lack systematic data, however, to bring the record up to the mid-1990s. 
Hungary, Lesotho, Thailand and Tunisia. (Remember that of the 75 developing non-qualifying countries, only 7 , or 9 percent of the cases, achieved growth of three percent or more, while of the qualifying countries, 11 , or 85 percent, achieved growth of three percent or more).

It is relatively straightforward to account for five of these six "exceptions." Botswana failed to qualify on the black-market premium for the 1970s, but did qualify for the 1980s. It passed all other criteria. Overall, therefore, the policies have been relatively well balanced, especially in the 1980s. Moreover, since around 80 percent of Botswana's exports are diamonds, and a remarkably small proportion (less than 5 percent) of the labor force is in agriculture, Botswana avoided the anti-agricultural biases of most of SubSaharan Africa.

As for Cape Verde, Hungary, and Tunisia, the "successful" growth during 1970-89 is more apparent than real. All three countries pursued statist development strategies that produced growth in the 1970 s and financial crises in the 1980s and early 1990s. In all three cases, there was a serious downturn in growth at the end of the 1980 s, as financial crises hit the government. Taken over a slightly longer time period, therefore, these cases would not look like successes and would not be anomalous.

Lesotho was excluded on the general grounds that it was expected to suffer from the worldwide boycott against South Africa. Otherwise it passed the remaining criteria. It appears that its small size (population 1.8 million) allowed Lesotho to make effective use of the South African market (both for goods and for migrant labor) even as South Africa itself was subjected to international sanctions.

Thalland is another example that qualifies on all the criteria except 
one: in this case our measure for extreme domestic unrest. It is disqualified because of the large number of coups in the 1970s and 1980s. But as is well known, these coups reflect a revolving door of Army Generals in an otherwise stable regime under the Thai King, and with a rather stable economic strategy. Therefore, unlike other countries characterized by domestic instability, the coups did not pose direct threats to private investors and therefore did not stifle Thai economic growth. Since Thailand was very open and otherwise pursued market-oriented policies, it has been a successful developing country. In effect, it should probably be classified as a qualifier, although adherence to our technical definitions put it into the non-qualifying camp ${ }^{20}$.

In our view, there is only one deep puzzle to these exceptions, the case of China. It is indeed true that China has violated most of the rules: obscure property rights, political repression, high black market premia on the yuan, extensive reliance on trade quotas. Nonetheless, China has experienced a boom. We believe that China's success is strongly related to its particular economic structure at the onset of its market reforms at the end of the $1970 \mathrm{~s}$. In particular, China was a very poor economy in 1978, with three-fourths of the labor force in peasant farming. The essence of Deng Xiaoping's reforms at the end of the 1970 s was to free the peasant economy from state controls, even while maintaining the state's grip on the non-peasant state-owned sector (which covered just 18 percent of the labor force).

This "two-track approach" (de-control of the peasant sector, with

20 Along these lines, we also ran regressions with Thailand classified as a qualifier. This slightly strengthened the political variables, but otherwise there was no material difference with the regressions reported here. For more detailed discussions of Thailand's case, see Laothamatas (1992) and Phongpaichit (1992). 
continued control of the state sector) was sufficient to unleash China's growth and labor-intensive export boom, even though it did not solve many problems of poor performance in the state-owned sector. Some analysts have also argued that its boom is fragile as well, and could still be stopped by macroeconomic instability characteristic of many economies part way between planning and a market economy. See Sachs and woo (1993) for further details of the two-track approach in China and the current macroeconomic problems.

\section{Regression Analysis}

We now turn to a regression analysis, to confirm and deepen these basic findings. Various regression estimates are reported in Table 4, showing the simple bivariate relationship between initial income in 1970 and subsequent growth between 1970 and 1989. We see in regression (1) the absence of convergence for the entire sample of countries (the coefficient on initial income is positive rather than negative, and is statistically insignificant). In regression (2) we see the strong evidence of convergence within the set of qualifying countries. The coefficient on initial income suggests that each percentage point rise in per capita income in 1970 reduces subsequent annual growth by .013 percentage points. Each doubling of 1970 income reduces annual growth by .92 percentage points $(-\ln (2) * 1.325)$. In regression (3), we confirm the absence of convergence among the non-qualifying countries.

The regressions in Table 5 confirm the growth effects of the political and openness variables in the overall sample. In regression (4), we regress annual economic growth on the logarithm of initial income and six dummy variables, for the three political and three openness criteria. For each of 
the variables, a value of 1 signifies "non-qualifying" and a value of 0 signifies "qualifying." Therefore, we should expect negative coefficients on each of these variables in the growth regression. This is indeed what we find. In each case, the coefficient signifies the effect on annual growth, in percentage point terms, of the failure to conform to the particular standard of policy. For example, an excessive black-market premium is estimated to be associated with 2.25 percentage points of reduced annual growth (t-statistic equal to 6.0). Extensive export controls in Sub-Saharan Africa are estimated to have reduced growth by 1.88 percentage points per year. Socialist countries grew on average by 1.27 percentage points per year more slowly than non-socialist countries, holding constant other factors. (Evidence from the post-socialist period in many of these countries suggests that the growth rates of the socialist countries were probably overstated during our period of observation).

In regression (5), we compress the criteria into two variables, a single political variable (PNQ) and an openness variable (ONQ). Again, a value of 1 on either variable signifies "non-qualifying" on the criterion. The openness variable is highly negative and statistically significant; while the political variable is also negative, but smaller in magnitude and not quite statistically significant.

In Table 6, regression (6), we replicate the basic Barro (1991) regression on cross-country growth for our sample and time period. We see that the basic Barro equation performs as expected over our sample and time period, with conditional convergence (a negative, significant coefficient on initial income), positive effects of educational attainment (though not significant), positive effects of the investment-GDP ratio, and negative 
effects of measures of political instability.

Regression (7) estimates the same equation but includes the two dummy variables for political and openness qualifications ( 1 for non-qualifiers, 0 for qualifiers). When we add PNQ and ONQ, we find that the political nonqualifiers grow, on average, by 1.04 percentage points less per year than the political qualifiers, while the openness non-qualifiers grow by 1.94 percentage points less than the openness qualifiers. The rest of the structural variables remain roughly the same as in regression (6), though the initial education levels are even less significant. This is consistent with our view that the growth rate over this period was determined less by initial human capital levels than by policy choices.

We attempted various experiments to interact the PNQ and ONQ dummy variables with the right-hand-side variables in the Barro equation, to see for example whether the effects of education, initial income, investment, and the like were different for the qualifiers and non-qualifiers. To our surprise, the interaction terms generally proved to be small and statistically insignificant. The effect of policy failure was therefore measured to result in a downward step in growth, without clearly affecting the conditional impacts of the other right-hand-side variables.

In equation ( 8 ), we add two variables to the basic growth equation that we have explored in earlier work. The first variable, PXI, is a measure of the raw-material intensity of the economy, based on the share of raw-materials exports in total exports in 1970 . The second variable, DTT, is a measure of the change in the terms of trade of the country during 1970-89. As we argued in Sachs and Warner (1994), there are reasons to belleve that resource-rich countries will experience lower growth than resource poor countries, all other 
things equal, because the natural resource base will push resources into the non-tradeables sector at the expense of the manufacturing tradeables sector. If, as is sometimes argued, the manufacturing sector is the site of technological spillovers and learning by doing, then the shift of resources to non-tradeables could slow aggregate growth in the medium and long term.

As in our earlier paper, we find in regression (8) that the natural resource proxy variable does indeed help to account for cross-country growth, and this is true even controlling for PNQ and ONQ. Specifically, countries that specialized in natural resource exports at the start of the period tended to grow more slowly than manufacturing exporters. There is also some evidence, though not statistically significant, that a rising terms-of-trade over the period raised average growth over the period. While the inclusion of the PXI variable seems to be Justified even after controlling for ONQ and PNQ (which remain highly significant in the regression), the presence of PXI tends to eliminate the statistical significance of the investment-to-GDP ratio. Raw-materials exporters systematically had lower rates of physical investment relative to GDP. When the equation must choose between PXI and investment-to-GDP as an explanation of growth, the PXI variable dominates ${ }^{21}$.

In other regressions, not reported in the table, we instrument the PXI variable in order to eliminate the possibility that high-resource intensity

21 We checked regression (8) for sensitivity to outlying observations by examining the residuals and leverage statistics (a measure for how far the data for a particular country differs from the cross-country means). We found that Sierra Leone and Guatemala have the highest leverage and that Jamaica and Syria have the highest residuals (there is no country that has a high value for both). When the regression was re-estimated without these observations, none of the estimated coefficients in regression (8) changed enough to alter the conclusions in the text about significance: indeed, most estimated coefficients rose in absolute value (the exception was the ONQ coefficient, which fell from -1.4 to about -1.2 ). 
of exports is a result of poor growth performance rather than a cause. As in Sachs and Warner (1994) we use an instrument suggested originally by Adrian Wood: the ratio of aggregate years of schooling in the country divided by total land area of the country. Countries with high schooling-to-land ratios should be expected, on Heckscher-Ohlin-Samuelson trade theoretic grounds, to be manufacturing exporters, while countries with low ratios should be rawmaterials exporters. The use of this instrument does not change our finding with regard to the negative effect of PXI on subsequent growth.

In regressions (9) and (10) we run the Barro equation, augmented by PXI and DTT, separately for the two subsets of countries, the qualifiers and the non-qualifiers. For the qualifying countries, in regression ( 9 ), the basic equation remains satisfactory, with evidence of conditional convergence (a negative, statistically significant effect of initial income on subsequent growth), and with the continuing importance of the PXI variable. For the nonqualifiers, in regression (10), there is also (surprising-though not quite significant) evidence of conditional convergence, with the initially poorer countries tending to grow faster after controlling for the other right-handside variables. Of course, the constant term in (10) is lower than in (9), reflecting the overall drag on growth of inappropriate policies.

In regression (8), we had found that PNQ and ONQ reduced overall growth when controlling for the other variables. Since poor policies might also affect the rates of investment relative to GDP and the rates of human capital accumulation, we would expect indirect adverse growth effects of poor policies as a result of slower capital accumulation (both physical and human). In regressions (11) - (13), we therefore check whether the qualifying and nonqualifying countries differed systematically in the rates of capital 
accumulation, once we control for initial income and resource-intensity of initial production (as proxied by PXI). In regression (11) we find that the openness non-qualifiers (ONQ - 1) had significantly lower investment-to-GDP ratios, with ONQ reducing the investment ratio by an average of 3.7 percentage points. ${ }^{22}$ Interestingly, there is also some evidence that richer countries have higher investment rates than poorer countries.

In regressions (12) and (13), we ask whether the increase in educational attainment between 1970 and 1985 was different for the two subsets of countries, again controlling for initial income levels and PXI. We find no evidence that the non-qualifiers had a lower improvement in the coverage of primary and secondary education than did the qualifiers. It is clear, though, that the more developed economies had less improvement in educational coverage than did the poorer countries (as evidenced by the significant, negative sign on initial income in both regressions).

Based on the regression analysis, we may make five conclusions:

(1) there is strong evidence of unconditional convergence for qualifying countries, and no evidence of unconditional convergence for non-qualifying countries; (2) non-qualifying countries grew systematically more slowly than did the qualifying countries, so that "good" policies mattered; (3) each of the policy criteria played a role in determining average growth rates; (4) the role of the policy criteria remains in place after controlling for other growth factors, as in a standard Barro cross-country growth equation; (5) poor policies seem to affect growth directly, controlling for other factors, while

22 We note that Levine and Renelt (1992), using trade shares as a measure of openness, also find that investment shares are higher in more open economies. This is also one of the few findings that they classify as robust, using extreme bounds analysis. 
poor trade policies also seemed to affect the rate of accumulation of physical capital.

\section{Discussion and Conclusions}

The absence of strong evidence across countries of unconditional economic convergence has led to a number of disparate views in the economics profession in recent years. Some have argued that non-convergence is a technological fact of life. Others have suggested that laggard countries require special remedial policies to provoke high-speed growth, lest they get trapped in a low-growth economy. Industrial policies a la East Asia have sometimes been posited as a model for such lagging countries. The evidence in this paper strongly calls into question these views.

A more parsimonious interpretation of the evidence is that convergent growth can be achieved by all or virtually all countries that follow a reasonable set of political and economic policies, including civil peace, basic adherence to political and civil rights, and (most decisively) an open economy, through the absence of trade quotas, export monopolies, or inconvertible currencies. All developing countries that followed such a pattern achieved per capita growth between 1970 and 1989 of two percent per year or greater.

We note again that many authors have introduced political and openness data into cross-country growth equations, and indeed we use many of the criteria suggested by others. Our contribution is not to show that trade "matters" for growth, since this has already been done. Our contribution, we believe, is to show the strength of convergence among all well-behaving countries. We believe that this simple and important fact has been obscured 
among growth theorists. Another way to summarize the message for the poorer countries is to consider the following matrix. In this matrix, the group of countries with real GDP in 1970 of less than $\$ 4,000$ are sorted in two dimensions: those that do or do not satisfy the criteria; and those that have grown quickly $(G 7089>3.0)$, moderately $(3.0>G 7089>2.0)$, and slowly (G7089 $(2,0)$.

\begin{tabular}{|l|c|c|}
\hline $\begin{array}{l}\text { All Countries } \\
\text { with GDP70<4000 }\end{array}$ & $\begin{array}{l}\text { Satisfy } \\
\text { Criteria }\end{array}$ & $\begin{array}{l}\text { Do Not Satisfy } \\
\text { Criteria }\end{array}$ \\
\hline $\begin{array}{l}\text { Fast Growth } \\
\text { (G7089>3.0) }\end{array}$ & 10 & 7 \\
\hline $\begin{array}{l}\text { Moderate Growth } \\
\text { (3>G7089>2) }\end{array}$ & 2 & 18 \\
\hline $\begin{array}{l}\text { Slow Growth } \\
\text { (G7089<2.0) }\end{array}$ & 0 & 51 \\
\hline
\end{tabular}

Most of the countries of course lie either in the upper left or lower right cells, reiterating the finding that growth is strongly associated with whether a country satisfies the criteria. What is surprising is that so few of the countries lie in the lower left or upper right cells. In particular, there is not a single country that falls in the bottom left cell, of good policies and slow growth. This fact lends support to the view that the criteria we consider are sufficient for growth. On the other hand, the fact that there are 7 countries in the upper right cell shows that these criteria are not necessary for growth: some countries have indeed grown rapidly without satisfying our criteria. We have argued, however, that in fact 6 of these 7 countries really conform with the general pattern, when difficulties with timing and specific patterns of policy are taken into account. Only China is really heterodox by our standards, and even there we have reasons to suspect 
that China's particular growth pattern could not easily be emulated by other countries.

The findings above may also be expressed in terms of conditional probabilities. Suppose a representative poor country back in 1970 found itself behind a Rawlsian "veil of Ignorance". The policy-makers could know the numbers in the matrix, but not the specifics of the country, in choosing which path to follow. Would such a country gamble that it would come out like China based on the numbers above? Conditional on closed policies, the probability of growing at 3 percent or more would be only 0.09 ( 7 divided by the 76 disqualified countries with low income). On the other hand, the gamble based on good policies would yield vastly better odds.

It is natural to ask whether our results are a case of reverse causation, in which slow economic growth led to bad policies - for example, if stagnant economies tried to experiment with trade barriers in order to speed economic growth. We think this is highly unlikely. In most cases, the "bad" policies were selected early in the post-war era, long before a track record on growth had occurred. These countries stuck with the policy choices until quite recently, certainly into the 1970 s and 1980 s, the interval of observation. Moreover, the few cases of developing countries that pursued outward oriented policies did so in part because of their particularly close security relations with the United States or with European nations. For these reasons, we believe that it is appropriate to take the policy regime "as given," for purposes of studying the effects of policy choices on growth. In a follow up study, we propose to examine the sources of basic development strategies of these nations, according to geography, colonial history (if any), date of independence and therefore experience of government, and 
economic structure.

In conclusion, we believe that are findings are significant. Dozens of countries in Latin America, Africa, Eastern Europe, and the former Soviet Union have recently undertaken market-reform policies that will shift them from the non-qualifying to the qualifying category of nations. Our results suggest that most or all of these reforming nations have a good chance to benefit from these reforms with higher economic growth. Indeed, we can already see the fruits of reform in several economies in Latin America (e.g. Argentina, Peru, Bolivia), in Asia (e.g. the Philippines), and in Africa (e.g. Mauritius, Botswana). 
Table 1. List of Non-qualifying Countries,

with score on ONQ and PNQ, growth rates and initial GDP

\begin{tabular}{|c|c|c|c|c|}
\hline & ONQ & PNQ & G7089 & GDP70 \\
\hline Algeria & 1 & 1 & 2.216 & 1833 \\
\hline Angola & 1 & 1 & -2.715 & 1110 \\
\hline Argentina & 1 & 1 & -0.758 & 4169 \\
\hline Bangladesh & 1 & 1 & 1.640 & 922 \\
\hline Benin & 1 & 1 & -0.935 & 1138 \\
\hline Bolivia & 1 & 1 & -0.046 & 1612 \\
\hline Botswana & 1 & 0 & 7.118 & 867 \\
\hline Brazil & 1 & 0 & 2.931 & 2390 \\
\hline Burkina Faso & 1 & 1 & 1.615 & 399 \\
\hline Burundi & 1 & 1 & 2.500 & 324 \\
\hline Cameroon & 1 & 1 & 2.145 & 866 \\
\hline Cape verde & na & a 1 & 3.267 & 689 \\
\hline Central African Rep. & 1 & 1 & -1.140 & 695 \\
\hline Chad & 1 & 1 & -1.848 & 543 \\
\hline Chile & 1 & 0 & 0.443 & 3695 \\
\hline China & 1 & 1 & 5.518 & 825 \\
\hline Colombia & 1 & 0 & 2.159 & 2100 \\
\hline Congo & 1 & 1 & 1.791 & 1581 \\
\hline Costa Rica & 1 & 0 & 1.302 & 2793 \\
\hline Cote d'Ivoire & 1 & 0 & -0.162 & 1322 \\
\hline Dominican Rep. & 1 & 0 & 2.282 & 1493 \\
\hline Ecuador & 1 & 1 & 2.482 & 1760 \\
\hline Egypt & 1 & 0 & 2.707 & 1101 \\
\hline E1 Salvador & 1 & 1 & -0.009 & 1740 \\
\hline Ethiopia & 1 & 1 & -0.094 & 287 \\
\hline Gabon & 1 & 1 & -0.094 & 3679 \\
\hline Gambia & 1 & 0 & 0.347 & 603 \\
\hline Ghana & 1 & 1 & -1.159 & 1017 \\
\hline Guatemala & 1 & 1 & 0.244 & 2004 \\
\hline Guinea & 1 & 1 & 0.103 & 353 \\
\hline Guinea-Bissau & 1 & 1 & -0.016 & 661 \\
\hline Guyana & 1 & 0 & -1.932 & 1711 \\
\hline Haiti & $\overline{0}$ & 1 & 0.040 & 787 \\
\hline Honduras & 1 & 0 & 0.599 & 1206 \\
\hline Hungary & 1 & 1 & 3.466 & 3373 \\
\hline India & 1 & 0 & 2.093 & 703 \\
\hline Iran, I.R. of & 1 & 1 & -1.696 & 4214 \\
\hline Iraq & 1 & 1 & -0.525 & 4270 \\
\hline Israel & 1 & 1 & 2.074 & 5705 \\
\hline Jamaica & 1 & 0 & -0.571 & 2688 \\
\hline Kenya & 1 & 0 & 2.236 & 582 \\
\hline Lesotho & 1 & 0 & 4.875 & 387 \\
\hline
\end{tabular}




\begin{tabular}{lllrr} 
Liberia & na & 1 & -1.090 & 949 \\
Madagascar & 1 & 0 & -2.668 & 1125 \\
Malawi & 1 & 1 & 0.816 & 431 \\
Mali & 1 & 1 & 1.781 & 389 \\
Mauritania & 1 & 1 & -0.697 & 881 \\
Mexico & 1 & 0 & 1.418 & 3951 \\
Mozambique & 1 & 1 & -3.408 & 1461 \\
Myanmar (Burma) & 1 & 1 & 2.037 & 392 \\
Nepal & 1 & 0 & 2.026 & 644 \\
Nicaragua & 1 & 1 & -2.008 & 2184 \\
Niger & 1 & 1 & -2.456 & 749 \\
Nigeria & 1 & 0 & -0.202 & 770 \\
Pakistan & 1 & 0 & 1.572 & 997 \\
Panama & na & 1 & 0.303 & 2501 \\
Papua New Guinea & 1 & 0 & -0.981 & 1744 \\
Paraguay & 1 & 0 & 2.368 & 1434 \\
Peru & 1 & 0 & -1.014 & 2642 \\
Philippines & 1 & 1 & 1.227 & 1369 \\
Poland & 1 & 1 & 2.286 & 2981 \\
Rwanda & 1 & 1 & 0.287 & 625 \\
Senegal & 1 & 0 & -0.120 & 1107 \\
Sierra Leone & 1 & 0 & -0.750 & 1050 \\
Somalia & 1 & 1 & 0.148 & 842 \\
South africa & 1 & 0 & 0.254 & 3160 \\
Sri Lanka & 1 & 1 & 2.825 & 1307 \\
Swaziland & 1 & 0 & -0.476 & 2390 \\
Syria & 1 & 1 & 2.763 & 2205 \\
Tanzania & 1 & 1 & 0.318 & 431 \\
Thailand & 0 & 1 & 4.072 & 1512 \\
Togo & 1 & 1 & 0.059 & 620 \\
Trinidad \& Tobago & 1 & 0 & 1.159 & 6715 \\
Tunisia & 1 & 0 & 3.601 & 1400 \\
Turkey & 1 & 0 & 2.321 & 2180 \\
Uganda & 1 & 1 & 0.879 & 763 \\
Uruguay & 1 & 0 & 0.572 & 3876 \\
Venezuela & 1 & 0 & -1.508 & 7607 \\
Yugoslavia & 1 & 1 & 2.854 & 3338 \\
Zaire & 1 & 1 & -2.429 & 643 \\
Zambia & 1 & 0 & -2.173 & 1096 \\
Zimbabwe & 1 & 1 & 0.987 & 1072 \\
& & & & \\
Average & & & 0.749 & \\
\hline & & & & \\
\hline
\end{tabular}

Notes: ONQ (ㅁppenness Non-Qualifier) is a dummy variable equal to 1 ( 1 means nonqualifier) if a country scores a 1 on either BMP, SOC, EXM or OWQID. PNQ (Politics Non-Qualifier) is a dummy variable equal to 1 if a country scores a 1 on either RIGHT, SOC, or EDU. See the data appendix for a more detailed description. G7089 is annual growth in real GDP per capita between 1970 and 1989 , using version 5.5 of the Summers-Heston data. GDP70 is real GDP per capita in 1970 (units are 1985 international dollars). 
Table 2. List of Qualifying Countries

\begin{tabular}{|c|c|c|}
\hline & G7089 & GDP70 \\
\hline Austra1ia & 1.636 & 10947 \\
\hline Austria & 2.620 & 7569 \\
\hline Barbados & 2.574 & 4768 \\
\hline Belgium & 2.324 & 8459 \\
\hline Canada & 2.956 & 10169 \\
\hline Cyprus & 3.907 & 3777 \\
\hline Denmark & 1.787 & 9698 \\
\hline Fin1and & 2.946 & 8272 \\
\hline France & 1.860 & 9625 \\
\hline Germany, West & 1.987 & 9586 \\
\hline Greece & 2.379 & 4236 \\
\hline Hong Kong & 6.229 & 4453 \\
\hline Indonesia & 5.098 & 699 \\
\hline Ireland & 2.894 & 4883 \\
\hline Italy & 2.542 & 7675 \\
\hline Japan & 3.349 & 7509 \\
\hline Jordan & 2.580 & 1409 \\
\hline Korea & 7.120 & 1680 \\
\hline Luxembourg & 2.516 & 10024 \\
\hline Malaysia & 4.010 & 2116 \\
\hline Malta & 5.409 & 2383 \\
\hline Mauritius & 4.465 & 2338 \\
\hline Morocco & 2.393 & 1303 \\
\hline Netherlands & 1.571 & 9241 \\
\hline New Zealand & 1.233 & 9352 \\
\hline Norway & 3.142 & 8144 \\
\hline Portugal & 3.374 & 3341 \\
\hline Singapore & 6.388 & 3156 \\
\hline Spain & 2.313 & 6025 \\
\hline Sweden & 1.628 & 10688 \\
\hline Switzerland & 1.237 & 13299 \\
\hline Taiwan & 6.742 & 2376 \\
\hline United Kingdom & 2.811 & 7703 \\
\hline United States & 1.954 & 12706 \\
\hline Yemen, N.Arab & 5.451 & 588 \\
\hline Average & 3.241 & \\
\hline
\end{tabular}

Note: These countries all score 0 on both the ONQ and PNQ variables. 
Table 3. Summary of Growth Performance

$\begin{array}{cc}\text { Number of } & \text { Mean } \\ \text { Countries } & \text { of } \mathrm{G} 7089\end{array}$

A11 Countries

117

1.495

High Income

Countries (GDP70>4000)

Qualifying

2.456

Non-Qualifying because of:

Politics alone

0

na

Openness alone

2

$-0.175$

Both

4

$-0.226$

Low Income

Countries (GDP70<4000)

Qualifying

12

4.745

Non-Qualifying because of:

$\begin{array}{lcc}\text { Politics alone } & 2 & 2.056 \\ \text { Openness alone } & 31 & 1.038 \\ \text { Both } & 40 & 0.598 \\ \text { (insufficient data) } & 3 & 0.827\end{array}$

Notes: The two high-income countries that are disqualified because of openness alone are Mexico and Trinidad. The four that are disqualified because of both criteria are Argentina, Iran, Iraq and Israel. The twelve low-income qualifying countries are Cyprus, Indonesia, Jordan, Korea, Malaysia, Malta, Mauritius, Morocco, Portugal, Singapore, Taiwan, and Yemen. The three lowincome countries with insufficient data are Cape Verde, Liberia, and Panama. All three are disqualified on the politics criteria, but since they are missing data on the openness criteria, it is not possible to classify them into the 'politics alone', 'openness alone' or 'both' classification. 


\section{Table 4. Simple Convergence Regressions}

Dependent Variable: 67089

\author{
A11 \\ Countries \\ A11 Qualifying
Countries
}

(1)

\begin{tabular}{lccc}
\hline $\begin{array}{l}\text { Constant } \\
\text { (t-ratio) }\end{array}$ & $\begin{array}{l}-1.239 \\
(-0.797)\end{array}$ & $\begin{array}{l}14.487 \\
(6.716)\end{array}$ & $\begin{array}{c}\text { (1.000) } \\
\text { LGDP70 }\end{array}$ \\
(t-ratio) & 0.362 & -1.325 & -0.185 \\
& $(1.774)$ & $(-5.238)$ & $(-0.643)$ \\
R Bar 2 & & \\
Mean of G7089 & 0.018 & 0.437 & -0.007 \\
Sigma & 1.495 & 3.241 & 0.749 \\
Sample Size & 2.171 & 1.226 & 1.975 \\
& 117 & 35 & 82 \\
\hline
\end{tabular}

Notes: All regressions in this paper report t-ratios below the estimated coefficients. G7089 is annual growth in real GDP per capita between 1970 and 1989, using version 5.5 of the Summers-Heston data. LGDP70 is the log of real per capita GDP in 1970 (in this case GDP70 is measured in thousands of 1985 internationa1 do1lars).
(2)

14.487

$-1.325$

0.437

1.226

A11 Excluded

Countries

(3)

2.077

$-0.185$

$-0.643)$

$-0.007$

0.749

1.975

82 
Table 5. Growth Effects of the Political and Openness Measures Dependent Variable: 67089

EDU

RIGHT

PNQ

BMP

OWQID

EXM

ONQ

LGDP70

R bar 2

Mean $\mathrm{dv}$.

Standard Error

Sample Size

Significance levels

for $F$ tests:

HO: $\beta(\mathrm{SOC})-\beta($ EDU $)-\beta($ RIGHT $)$

HO: $\beta($ BMP $)-\beta($ EXM $)-\beta$ (OWQID)

$\mathrm{HO}: \beta(\mathrm{PNQ})-\beta(\mathrm{ONQ})$

0.035
(4)

$$
9.912
$$

$(5.344)$

$-1.267$

$(-1.820)$

(5)

$$
8.282
$$

(4.408)

$-0.624$

$(-1.391)$

$-0.670$

$(-1.227)$

$-0.764$

$(-1.852)$

$-2.246$

$(-6.026)$

$-0.848$

$(-1.958)$

$-1.885$

$(-3.584)$

$-2.770$

$(-5.851)$

$-0.839$

$(-3.800)$

$-0.568$

$(-2.595)$

0.446

0.311

1.583

1.587

95

1.512

1.824

114

0.008

Notes: SOC is a dummy variable equal to 1 for Socialist countries. EDU is a 
dummy varlable equal to 1 for countries with extremely disruptive unrest. RIGHT is a dummy variable equal to 1 for countries with a very high degree of political repression. BMP is a dummy varlable equal to 1 for countries with high black market exhange rate premia during either the 1970 s or the 1980 s. OWQID is a dummy variable equal to 1 for countries with high coverage of quotas on intermediates and capital good imports. EXM is a dummy variable equal to 1 for countries with highly regulated, state-run, export monopolies. PNQ equals 1 if either SOC, EDU, or RIGHT equals 1, 0 otherwise; ONQ equals 1 if either BMP, OWQID, SOC or EXM equals 1,0 otherwise. The data appendix has further details. 
Table 6. Growth Regressions based on Barro (1991)

Dependent Variable: G7089

(6)

\begin{tabular}{|c|c|c|c|c|c|}
\hline $\begin{array}{l}\text { Constant } \\
\text { (t-ratio) }\end{array}$ & $\begin{array}{c}7.036 \\
(2.470)\end{array}$ & $\begin{array}{l}12.186 \\
(2.654)\end{array}$ & $\begin{array}{l}17.497 \\
(5.704)\end{array}$ & $\begin{array}{l}30.114 \\
(6.880)\end{array}$ & $\begin{array}{c}9.422 \\
(2.133)\end{array}$ \\
\hline ONQ & & $\begin{array}{l}-1.941 \\
(-4.175)\end{array}$ & $\begin{array}{c}-1.404 \\
(-2.848)\end{array}$ & & \\
\hline PNQ & & $\begin{array}{l}-1.038 \\
(-2.293)\end{array}$ & $\begin{array}{l}-0.990 \\
(-2.176)\end{array}$ & & \\
\hline LGDP70 & $\begin{array}{c}-1.013 \\
(-2.588)\end{array}$ & $\begin{array}{l}-1.361 \\
(-3.926)\end{array}$ & $\begin{array}{c}-1.841 \\
(-4.808)\end{array}$ & $\begin{array}{l}-2.915 \\
(-5.942)\end{array}$ & $\begin{array}{l}-0.989 \\
(-1.728)\end{array}$ \\
\hline SEC70 & $\begin{array}{c}3.732 \\
(1.729)\end{array}$ & $\begin{array}{c}2.149 \\
(1.125)\end{array}$ & $\begin{array}{c}3.738 \\
(1.866)\end{array}$ & $\begin{array}{c}1.772 \\
(0.904)\end{array}$ & $\begin{array}{c}3.237 \\
(0.874)\end{array}$ \\
\hline PRI70 & $\begin{array}{c}0.324 \\
(0.302)\end{array}$ & $\begin{array}{c}0.272 \\
(0.291)\end{array}$ & $\begin{array}{c}1.272 \\
(1.125)\end{array}$ & $\begin{array}{l}-1.416 \\
(-0.933)\end{array}$ & $\begin{array}{c}1.034 \\
(0.668)\end{array}$ \\
\hline GVXDXE & $\begin{array}{l}-5.818 \\
(-1.574)\end{array}$ & $\begin{array}{l}-6.456 \\
(-1.985)\end{array}$ & $\begin{array}{l}-8.318 \\
(-2.521)\end{array}$ & $\begin{array}{c}1.122 \\
(0.173)\end{array}$ & $\begin{array}{l}-6.153 \\
(-1.581)\end{array}$ \\
\hline REVCOUP & $\begin{array}{l}-0.358 \\
(-0.405)\end{array}$ & $\begin{array}{c}0.840 \\
(0.998)\end{array}$ & $\begin{array}{c}0.856 \\
(1.011)\end{array}$ & $\begin{array}{c}-3.402 \\
(-1.802)\end{array}$ & $\begin{array}{c}0.236 \\
(0.246)\end{array}$ \\
\hline ASSASSP & $\begin{array}{c}-1.931 \\
(-1.211)\end{array}$ & $\begin{array}{c}-1.354 \\
(-0.981)\end{array}$ & $\begin{array}{c}-1.652 \\
(-1.111)\end{array}$ & $\begin{array}{l}-1.848 \\
(-0.175)\end{array}$ & $\begin{array}{l}-2.670 \\
(-1.584)\end{array}$ \\
\hline PPI7ODEV & $\begin{array}{l}-0.993 \\
(-2.240)\end{array}$ & $\begin{array}{l}-0.909 \\
(-2.337)\end{array}$ & $\begin{array}{l}-1.088 \\
(-2.829)\end{array}$ & $\begin{array}{c}0.679 \\
(0.389)\end{array}$ & $\begin{array}{l}-1.011 \\
(-2.212)\end{array}$ \\
\hline INV7089 & $\begin{array}{l}11.954 \\
(3.314)\end{array}$ & $\begin{array}{c}7.769 \\
(2.363)\end{array}$ & $\begin{array}{c}4.736 \\
(1.415)\end{array}$ & $\begin{array}{l}-0.029 \\
(-0.009)\end{array}$ & $\begin{array}{c}4.680 \\
(0.937)\end{array}$ \\
\hline PXI71 & & & $\begin{array}{c}-2.454 \\
(-3.472)\end{array}$ & $\begin{array}{l}-3.050 \\
(-4.849)\end{array}$ & $\begin{array}{l}-2.592 \\
(-2.183)\end{array}$ \\
\hline DTT7189 & & & $\begin{array}{c}0.729 \\
(1.287)\end{array}$ & $\begin{array}{l}-0.591 \\
(-0.642)\end{array}$ & $\begin{array}{c}0.101 \\
(0.135)\end{array}$ \\
\hline $\begin{array}{l}\mathrm{R} \text { bar } 2 \\
\text { Mean dv. } \\
\text { s.e. } \\
\mathrm{N}\end{array}$ & $\begin{array}{r}0.364 \\
1.587 \\
1.644 \\
81\end{array}$ & $\begin{array}{r}0.528 \\
1.638 \\
1.415 \\
79\end{array}$ & $\begin{array}{l}0.586 \\
1.635 \\
1.353 \\
73\end{array}$ & $\begin{array}{r}0.805 \\
3.195 \\
0.764 \\
27\end{array}$ & $\begin{array}{l}0.228 \\
0.711 \\
1.513 \\
47\end{array}$ \\
\hline
\end{tabular}

Notes: SEC70 is the secondary school enrollment rate. PRI70 is the primary school enrollment rate. GVXDXE is the ratio of real government 'consumption' spending net of spending on the military and education to real GDP. REVCOUP 
is the number of revolutions and coups per year, averaged over the period 1970-1985. ASSASSP is the average number of assassinations per million population, 1970-1985. PPI70DEV measures the relative price of investment goods: the deviation of the $10 \mathrm{~g}$ of the price level of investment (PPP I / Xrate relative to the U.S.) from the cross country sample mean in 1970. INV7089 is the ratio of real gross domestic investment (public plus private) to real GDP, averaged over the period 1970-1989. PXI71 is the ratio of exports of primary products to total exports in 1971 . DTT7189 is the change in the $\log$ of the external terms of trade between 1971 and 1989. 
Table 7. The Effects on Human and Physical Capital Accumulation

Dependent Variables:

INV7089 DSYR DPYR
IN

(11)

(12)

(13)

\begin{tabular}{lccc}
\hline $\begin{array}{l}\text { Constant } \\
\text { (t-ratio) }\end{array}$ & -0.127 & 0.141 & 0.171 \\
ONQ & $(-1.648)$ & $(3.108)$ & $(4.496)$ \\
& -0.037 & 0.004 & 0.005 \\
PNQ & $(-2.091)$ & $(0.424)$ & $(0.569)$ \\
& 0.009 & 0.002 & -0.005 \\
LGDP70 & $(0.592)$ & $(0.215)$ & $(-0.693)$ \\
& 0.048 & -0.012 & -0.018 \\
PXI71 & $(5.621)$ & $(-2.352)$ & $(-4.378)$ \\
& -0.043 & -0.007 & -0.006 \\
R bar 2 & $(-1.687)$ & $(-0.458)$ & $(0.500)$ \\
Mean d.v. & 0.526 & 0.078 & 0.247 \\
S.e. & 0.187 & 0.048 & 0.024 \\
N & 0.061 & 0.033 & 0.027 \\
& 103 & 90 & 85 \\
\hline
\end{tabular}

Notes: INV7089 is the ratio of public and private investment spending to GDP, averaged over the period 1970-1989. DSYR is average accumulation of secondary schooling over the period 1970-1985. Specifically, DSYR - [ $\log ($ SYR85) $\log (S Y R 70)] / 15$, where SYRxx is person-years of secondary schooling divided by the total population over age 15. DPYR is accumulation of primary schooling, similarly calculated. 


\section{DATA APPENDIX}

The data set in this paper begins with the sample of 135 countries included in the Summers and Heston data set. For most of these countries, the growth variable (G7089) was calculated directly from the Summers and Heston data. For seven countries, Comoros, Ethiopia, Liberia, Tanzania, Nicaragua, Iraq, and Nepal, growth was calculated using 1985 data rather than 1989 data. Growth is measured as annual growth in per-capita real GDP, and is expressed in a common set of prices (1985 international prices, in the Summers and Heston terminology).

Out of this universe of 135 countries, there were 13 countries that did not have adequate growth data, either because it was not available at all, or because it was not available for a sufficiently long time span. These countries were Afghanistan, Bahamas, Bahrain, Dominica, Grenada, Kuwait, Oman, St. Lucia, St. Vincent, Solomon Islands, Saudi Arabia, Sudan, and United Arab Emirates. So, in summary, there were 122 countries with adequate growth data.

We also examined a large set of variables in an attempt to measure concepts such as respect for contracts and property rights, lack of wars and civil unrest, and integration with the world economy. The variables we ended up using are the following:

BMP70 and BMP80 Black market exchange rate premium, averaged over the decade of the 1970's and 1980's respectively. Source: Picks Currency Yearbook with updates from World Bank data (supplied by Ross Levine with help from Jong-wha Lee).

BMP

Dummy variable equal to 1 if either BMP70>0.2 or BMP80 $>0.2$.

EXM

Dummy variable equal to 1 if a country had a score of 4 on the export crop marketing index, page 238 of the World Bank study, Adjustment in Africa. A score of 4 means that the country had a public sector monopoly in purchasing and exporting products at prices not linked to world market prices. The study covered African countries only.

SOC

Dummy variable equal to 1 if the country was classified as Socialist in Kornai, table 1.1.

OWQI

Variable indicating extent of quotas on imports of intermediates and capital goods. It is the fraction of code lines involving capital goods or intermediates, that are covered by some sort of quantitative restriction on imports. Includes licensing, prohibitions and quotas. Developed from UNCTAD data by Jong tha Lee (1993). Period covered is 1985-1988.

OWQID

Dummy variable equal to 1 if OWQI $>0.4$.

RIGHT

Dummy variable equal to 1 if a country scored a 6 or above (higher means more repressive) on either the political 
rights index or the civil liberties index in Macmillan, Rauser and Johnson, table 1, pp. 8-10.

Dummy variable equal to 1 in cases of 'Extremely Disruptive Unrest'. Intended to capture disruptive internal or external wars, coups and revolutions. Constructed by the authors using several indicators. First, countries were assigned a 1 if they scored a 0.6 or higher on the REVC70 or REVC80 index in Barro and Lee (1993). In addition, the following countries were assigned a 1 because of conflicts: Angola (16 year civil war); Burundi (Hutu rebellion in 1973-74 resulting in an estimated 160,000 deaths); Chad (repeated battles with Moslem rebels in the north); E1 Salvador (12 year civil war); Ethiopia (extended war with Somalia over control of the Ogaden region of Ethiopia); Guatemala (repeated conflicts between the military rulers and the guerrilla army of the poor); Iran and Iraq (war in the early 1980's); Israel; Mozambique (protracted civil war in the 1980's); Nicaragua (civil war); Panama (U.S. invasion in the late 1980's); Somalia (see Ethiopia); Sri Lanka (repeated violence with the Tamil and Sinhalese separatists); Uganda (invasion by Tanzania); Zimbabwe (revolt against government of $\operatorname{Ian} \mathrm{Smith}$ in the late 1970 's).

When countries had missing data on these variables, we made some attempt to fill in the data. The list of these adjustments is as follows. Hungary and Yugoslavia were assigned a 1 and Cote D'Ivoire and Hong Kong were assigned a 0 for RIGHT. South Africa, Lesotho and Swaziland were assigned a 1 on OWQI, because trade sanctions against South Africa restricted trade between these countries and the rest of the world during most of the 1970-1989 period. Australia, Luxembourg, Malta, and New Zealand were assigned a 0 on OWQI. Even though the trade policies of Australia and New Zealand have been fairly restrictive by OECD standards, we do not think they have been extremely restrictive by world standards.

After filling in these missing data, there remained five small countries for which we had insufficlent data to make an informed assessment: Comoros, Iceland, Fiji, Seychelles, and Suriname. Adding these 5 countries to the 13 excluded for lack of growth data, there were 18 countries excluded from the sample for lack of data, reducing the sample size from 135 to 117 .

The two tables below list the countries that were disqualified on either openness (Table A1) or 'politics' (Table A2). The tables also report the values for the main dummy variables, to show exactly why a particular country was disqualified. The list of qualifying countries can be obtained from tables 1 and 2 in the text. The 1 ist of openness qualifiers are all the countries in table 2 plus the countries with ONQ-0 in table 1 . The list of 'politics' qualifiers are all the countries in table 2 plus the countries with PNQ-0 in table 1. 
Table Al. List of Countries Disqualified on Openness Grounds, with Reason for Disqualification (1 means disqualified)

\begin{tabular}{|c|c|c|c|c|}
\hline COUNTRY & BMP & EXM & soc & OWQID \\
\hline Algeria & 1 & 0 & 0 & 0 \\
\hline Angola & 1 & 0 & 1 & 0 \\
\hline Argentina & 1 & 0 & 0 & 0 \\
\hline Bangladesh & $\overline{1}$ & 0 & 0 & 1 \\
\hline Benin & 0 & 1 & 1 & 0 \\
\hline Bolivia & 1 & 0 & 0 & 0 \\
\hline Botswana & 1 & 0 & 0 & na \\
\hline Brazil & 1 & 0 & 0 & 0 \\
\hline Burkina Faso & 0 & 1 & 0 & 1 \\
\hline Burundi & 1 & 1 & 0 & 0 \\
\hline Cameroon & 0 & 1 & 0 & 0 \\
\hline Central African & 0 & 1 & 0 & 0 \\
\hline Chad & 0 & 1 & 0 & na \\
\hline Chile & 1 & 0 & 0 & 0 \\
\hline China & na & 0 & 1 & 0 \\
\hline Colombia & 0 & 0 & 0 & 1 \\
\hline Congo & 0 & 1 & 1 & 0 \\
\hline Costa Rica & 1 & 0 & 0 & 1 \\
\hline Cote d'Ivoire & 0 & 1 & 0 & na \\
\hline Dominican Republ & 1 & 0 & 0 & na \\
\hline Ecuador & 1 & 0 & 0 & 0 \\
\hline Egypt, Arab Repu & 1 & 0 & 0 & 0 \\
\hline El Salvador & 1 & 0 & 0 & 0 \\
\hline Ethiopia & 1 & 0 & 1 & 0 \\
\hline Gabon & 0 & 1 & 0 & na \\
\hline Gambia, The & 0 & 1 & 0 & $\mathrm{n}$ \\
\hline Ghana & 1 & 1 & 0 & 0 \\
\hline Guatemala & 0 & 0 & 0 & 1 \\
\hline Guinea & na & 1 & 0 & 0 \\
\hline Guinea-Bissau & na & 1 & 0 & na \\
\hline Guyana & 1 & 0 & 0 & 0 \\
\hline Honduras & 0 & 0 & 0 & 1 \\
\hline Hungary & na & 0 & 1 & na \\
\hline India & 1 & 0 & 0 & 1 \\
\hline Iran, Islamic $\operatorname{Re}$ & 1 & 0 & 0 & 1 \\
\hline Iraq & 1 & 0 & 0 & 0 \\
\hline Israel & 1 & 0 & 0 & na \\
\hline Jamaica & 1 & 0 & 0 & 0 \\
\hline Kenya & 1 & 0 & 0 & 0 \\
\hline Lesotho & 0 & 0 & 0 & 1 \\
\hline Madagascar & na & 1 & 0 & 0 \\
\hline Malawi & 1 & 1 & 0 & 1 \\
\hline Ma1i & 0 & 1 & 0 & na \\
\hline Mauritania & 1 & 1 & 0 & na \\
\hline Mexico & 1 & 0 & 0 & 0 \\
\hline
\end{tabular}




\begin{tabular}{|c|c|c|c|c|}
\hline Mozambique & 1 & 1 & 1 & 0 \\
\hline Myanmar & 1 & 0 & 0 & na \\
\hline Nepal & 1 & 0 & 0 & 0 \\
\hline Nicaragua & 1 & 0 & 1 & 1 \\
\hline Niger & 0 & 1 & 0 & na \\
\hline Nigeria & 1 & 1 & 0 & 0 \\
\hline Pakistan & 1 & 0 & 0 & 0 \\
\hline Papua New Guinea & 1 & 0 & 0 & 0 \\
\hline Paraguay & 1 & 0 & 0 & 0 \\
\hline Peru & 1 & 0 & 0 & 0 \\
\hline Philippines & 0 & 0 & 0 & 1 \\
\hline Poland & na & 0 & 1 & na \\
\hline Rwanda & 1 & 1 & 0 & 1 \\
\hline Senegal & 0 & 1 & 0 & 0 \\
\hline Sierra Leone & 1 & 1 & 0 & 0 \\
\hline Somalia & 1 & 0 & 1 & 0 \\
\hline South Africa & 0 & 0 & 0 & 1 \\
\hline Sri Lanka & 1 & 0 & 0 & 0 \\
\hline Swaziland & 0 & 0 & 0 & 1 \\
\hline Syrian Arab Repu & 1 & 0 & 0 & 1 \\
\hline Tanzania & $\overline{1}$ & 1 & 0 & 0 \\
\hline Togo & 0 & 1 & 0 & na \\
\hline Trinidad and Tob & 1 & 0 & 0 & 0 \\
\hline Tunisia & 0 & 0 & 0 & 1 \\
\hline Turkey & 0 & 0 & 0 & 1 \\
\hline Uganda & 1 & 1 & 0 & 0 \\
\hline Uruguay & 1 & 0 & 0 & 0 \\
\hline Venezuela & 1 & 0 & 0 & 0 \\
\hline Yugoslavia & na & 0 & 1 & na \\
\hline Zaire & 1 & 0 & 0 & 0 \\
\hline Zambia & 1 & 1 & 0 & 0 \\
\hline Zimbabwe & 1 & 0 & 1 & 1 \\
\hline
\end{tabular}

Countries with insufficient data for a final classification:

$\begin{array}{rllll}\text { Cape Verde } & \text { na } & 0 & 0 & \text { na } \\ \text { Liberia } & 0 & 0 & 0 & \text { na } \\ \text { Panama } & 0 & 0 & 0 & \text { na }\end{array}$

Notes: See above (data appendix) for description of the variables. 
Table A2. List of Countries Disqualified for 'Political' reasons, with Reason for Disqualification ( 1 means disqualification)

$\begin{array}{llll}\text { COUNTRY } & \text { RIGHT } & \text { SOC } & \text { EDU }\end{array}$

\begin{tabular}{|c|c|c|c|}
\hline Algeria & 1 & 0 & 0 \\
\hline Angola & 1 & 1 & 1 \\
\hline Argentina & 0 & 0 & 1 \\
\hline Bangladesh & 0 & 0 & 1 \\
\hline Benin & 1 & 1 & 0 \\
\hline Bolivia & 0 & 0 & 1 \\
\hline Burkina Faso & 0 & 0 & 1 \\
\hline Burund1 & 1 & 0 & 1 \\
\hline Cameroon & 1 & 0 & 0 \\
\hline Cape Verde & $\overline{1}$ & 0 & 0 \\
\hline Central African & 1 & 0 & 1 \\
\hline Chad & 1 & 0 & 1 \\
\hline China & 1 & 1 & 0 \\
\hline Congo & 1 & 1 & 0 \\
\hline Ecuador & 0 & 0 & 1 \\
\hline E1 Salvador & 0 & 0 & 1 \\
\hline Ethiopia & 1 & 1 & 1 \\
\hline Gabon & 1 & 0 & 0 \\
\hline Ghana & 0 & 0 & 1 \\
\hline Guatemala & 0 & 0 & 1 \\
\hline Guinea & 1 & 0 & 0 \\
\hline Guinea-Bissau & 1 & 0 & 1 \\
\hline Haiti & 1 & 0 & 0 \\
\hline Hungary & 1 & 1 & 0 \\
\hline Iran, Islamic Re & 0 & 0 & 1 \\
\hline Iraq & 1 & 0 & 1 \\
\hline Israel & 0 & 0 & 1 \\
\hline Liberia & 0 & 0 & 1 \\
\hline Malawi & 1 & 0 & 0 \\
\hline Mali & 1 & 0 & 0 \\
\hline Mauritania & 1 & 0 & 0 \\
\hline Mozambique & 1 & 1 & 1 \\
\hline Myanmar & 1 & 0 & 0 \\
\hline Nicaragua & 0 & 1 & 1 \\
\hline Niger & 1 & 0 & 0 \\
\hline Panama & 0 & 0 & 1 \\
\hline Philippines & 0 & 0 & 1 \\
\hline Poland & 1 & 1 & 0 \\
\hline Rwanda & 1 & 0 & 0 \\
\hline Somalia & 1 & 1 & 1 \\
\hline Sri Lanka & 0 & 0 & 1 \\
\hline Syrian Arab Repu & 1 & 0 & 0 \\
\hline Tanzanía & 1 & 0 & 0 \\
\hline That land & 0 & 0 & 1 \\
\hline Togo & 1 & 0 & 0 \\
\hline Uganda & 0 & 0 & 1 \\
\hline Yugoslavia & 1 & 1 & 0 \\
\hline
\end{tabular}


Zaire

1

0

0

Zimbabwe

0

$1 \quad 1$

Notes: See above (data appendix) for description of the variables. 
Descriptions for the other variables used in this paper, along with sources, are given below.

GDP70 Real GDP per capita from Summers and Heston version 5.5 in 1970 (1985 International Prices).

GDP89

Same variable for 1989 .

G7089

Real per capita growth rate of GDP, per annum: G7089 = [LN(GDP89) - LN(GDP70)] $/ 19$.

SEC70

PRI70

GVXDXE

REVCOUP

ASSASSP

PPI70DEV

INV7089

PXI71
Secondary school enrollment rate. Source: Barro and Lee, 1994.

Primary school enrollment rate. Source: Barro and Lee, 1994.

Ratio of real government 'consumption' spending net of spending on the military and education to real GDP. Source: Barro and Lee, 1994, who in turn used Summers and Heston v. 5.5.

Number of revolutions and coups per year, averaged over the period 1970-1985. Source Barro and Lee, 1994.

Number of assassinations per million population per year, 19701985. Source: Barro and Lee, 1994.

The deviation of the $\log$ of the price level of investment (PPP I / Xrate relative to the U.S.) from the cross country sample mean in 1970. Source: Authors calculation based on the PISH5 price data in Barro and Lee, 1994.

Ratio of real gross domestic investment (public plus private) to real GDP, averaged over the period 1970-1989. Source: Barro and Lee, 1994, who in turn used Summers and Heston v. 5.5.

Primary export intensity in 1971. Ratio of exports of SITC (revision 1) categories $0,1,2,3,4$, and 68 to total exports in 1971, with both the numerator and denominator expressed in nominal dollars. These SITC categories include: food and live animals, beverages and tobacco, inedible crude materials, oils and fats, mineral fuels and lubricants and related materials, and non-ferrous metals. Source: World Bank, World Tables, 1993, for all countries except Taiwan, Singapore and South Africa. Data for Taiwan was obtained from the Taiwan Statistical Data Book, 1992. Data for South Africa was obtained from Bulletin of Statistics, The Republic of South Africa, Pretoria, Dec. 1972 and June 1992, (exports of raw diamonds and gold were included). Data for Singapore was estimated as 0.01 based on GDP and labor force data indicating that Singapore produces no mining, no primary energy and only a very small amount of agriculture, forestry and fishing products. The data for Bangladesh is for 1972 rather than 1971. The data for Cameroon was set to 1.0 it exceeded 1.0 using the published data. 
Change in the log of the external terms of trade between 1971 and 1989. DTT7189 - LN(TT89) - LN(TT71), where TT 1s the ratio of a U.S. dollar export price index (1987-100) to an import price index in similar units. Source: World Bank, World Tables, 1993, and National statistical sources for Taiwan and South Africa. 


\section{REFERENCES}

Adjustment in Africa, World Bank, New York, Oxford University Press, 1994.

Alesina, A S. Ozler, N. Roubini, and P. Swagel, Political Instability and Economic Growth, NBER Working Paper No. 4173, 1992

Barro, R. and X. Sala-i-Martin, "Convergence Across States and Regions," Brookings Papers on Economic Activity, 1991:1

Barro, R., "Economic Growth in a Cross Section of Countries, " Quarterly Journal of Economics 106, 1991, 407-444.

Barro, R. and X. Sala-i-Martin, "Convergence," Journal of Political Economy, Vol. 100, No. 2, 1992

Barro, R. and X. Sala-i-Martin, "Regional Growth and Migration: A Japan-United States Comparison," Journal of Japanese and International Economics, 6, 1992, pp. 312-346

Barro, R. and Jong-Wha Lee, "International Comparisons of Educational Attainment," Journal of Monetary Economics 32, 1993, 363-394.

Baumol, William J., Richard R. Nelson, Edward N. Wolff (eds.), Convergence of Productivity, New York: Oxford University Press, 1994.

Ben-David, Dan. "Equalizing exchange: trade liberalization and income convergence." Quarterly Journal of Economics, August 1993, v108, n3, p653(27).

Bhalla, Surjit S., "Freedom and Economic Growth: A Virtuous Cycle," presented at Nobel Symposium on Democracies, Victory and Crisis at Uppsala University, Sweden, August 27-30, 1994.

DeLong J. B. "Productivity Growth, Convergence and Welfare: A Comment", American Economic Review, 78, December 1988, 1138-54.

Dollar, David, "Outward Oriented Economies Really do Grow More Rapidly: Evidence from 95 LDCs, 1976-1985," Economic Development and Cultural Change $40,1992,523-544$.

Dowrick, Steve, and Duc-Tho Nguyen, "OECD Comparative Economic Growth 1950-1985: Catch-up and Convergence," American Economic Review, 79, pp. 1010-30

Grossman, Gene, and Elhanan Helpman, Innovation and Growth in the Global Economy, Cambridge: MIT Press, 1991.

Helliwe11, J. F. "International Growth Linkages: Evidence from Asia and the OECD." National Bureau of Economic Research Working Paper No. 4245. December 1992 . 
Eicher, T. S. "Trade and Converging Growth Rates in a Model with Endogenous Human Capital and Technological Change." Unpublished paper, Columbia University, December, 1993.

King, Robert and Ross Levine, "Finance and Growth: Schumpeter Might be Right," Quarterly Journal of Economics 108, 1993, 717-738.

Kormend1, Roger and Philip Mequire, "Macroeconomic Determinents of Growth," Journal of Monetary Economics 16, 1985, 141-163.

Kornal, Janos, The Soclalist System: The Political Economy of Communism, Princeton, N.J.: Princeton University Press, 1992.

Krishna, Pravin and Devashish Mitra, "Trade Liberalization, Market Discipline and Productivity Growth: New Evidence from India." Unpublished paper, Columbia University, December 1994.

Laothamatos, Anek, "The Politics of Structural Adjustment in Tha1land: a Political Explanation of Economic Success", in Andrew Macintyre and Kanishka Jayasuriya eds. The Dynamics of Economic Policy Reform in South-East Asia and the South-West Pacific, Oxford: Oxford University Press, 1992.

Lee, Jong-Wha, "International Trade, Distortions, and Long-Run Economic Growth," IMF Staff Papers, vol. 40, No. 2, June 1993, 299-328.

Levine, Ross and David Renelt, "A Sensitivity Analysis of Cross-Country Growth Regressions," American Economic Review 82, 1992, 942-963.

Lucas, Robert, "On the Mechanics of Economic Development," Journal of Monetary Economics, 22, 1988, 3-42.

Mankiw, Gregory, David Romer, and David We1l, "A Contribution to the Empirics of Economic Growth, " Quarterly Journal of Economics 106, 1992, 407-437.

McMillan, John C., Gordon C. Rausser, and Stanley R. Johnson, "Economic Growth, Political and Civil Liberties," Occasional Paper No. 53, International Center for Economic Growth, San Francisco: ICS Press, 1994.

Phongpaichit, Pasuk, "Technocrats, Businessmen and Generals: Democracy and Economic Policy Making in Thailand", In Andrew Macintyre and Kanishka Jayasuriya eds. The Dynamics of Economic Policy Reform in South-East Asia and the South-West Pacific, Oxford: Oxford University Press, 1992.

Pritchett, Lant, "Measuring Outward Orientation in Developing Countrles: can it be done?", WPS Working Paper No. 566, The World Bank, October 1993.

Romer, Paul M., "Increasing Returns and Long-Run Growth, "Journal of Political Economy, 1986, vol. 94, no. 5, pp. 1002-1037. 
Romer, Paul M., "Endogenous Technological Change," Journal of Political Economy, 1990, vol. 98, no. 5, pt. 2, pp. s71-S102.

Svensson, Jakob, Investment. Property Rights, and Political Instability: Theory and Evidence, Seminar Paper 575, Institute for International Economic Studies, University of Stockholm. July 1994.

Sachs, Jeffrey D., and Andrew M. Warner, Natural Resources and Economic Growth., Unpublished Paper, Harvard University, August 1994.

Williamson, J. G. "The Evolution of Global Labor Markets in the First and Second World Since 1830: Background Evidence and Hypotheses." National Bureau of Economic Research, SAE Working Paper no. 36, February 1992.

Williamson, J. G. "Economic Convergence: Placing Post-famine Ireland In Comparative Perspective." Discussion Paper No. 1654, Harvard Institute of Economic Research. September 1993.

Wolf, Holger, "Convergence Reconsidered", Weltwirtschaftliches Archiv, December, 1994.

Young, Alwyn, "Learning by Doing and the Dynamic Effects of International Trade." Quarterly Journal of Economics, May 1991, vol. CVI, No. 2, pp. 369-406. 